\title{
Foliar application of calcium chloride and calcium silicate decreases white mold intensity on dry beans
}

\author{
Trazilbo J. Paula Júnior ${ }^{1}$, Rogério F. Vieira ${ }^{1}$, Hudson Teixeira² ${ }^{2}$ José Eustáquio S. Carneiro² \\ ${ }^{1}$ Empresa de Pesquisa Agropecuária de Minas Gerais - Epamig, 36570-000 Viçosa, MG, Brazil; ${ }^{2}$ Departamento de Fitotecnia, \\ Universidade Federal de Viçosa, 36570-000, Viçosa, MG, Brazil
}

Author for correspondence: Trazilbo J. Paula Júnior, e-mail: trazilbo@epamig.br

\begin{abstract}
White mold (Sclerotinia sclerotiorum) is the most important common bean disease during the fall-winter season in Brazil. Different control strategies are necessary to control this disease and increase bean yield in infested areas. The aim of this research was to evaluate the effect of application of calcium chloride $\left(\mathrm{CaCl}_{2}\right)$ and calcium silicate $\left(\mathrm{CaSiO}_{3}\right)$ on white mold control on common bean. The experiment was carried out during the 2006 fall-winter season in Viçosa MG, Brazil, in a field naturally infested with sclerotia. $\mathrm{Both}^{\mathrm{CaCl}} \mathrm{and} \mathrm{CaSiO}_{3}$ were applied at 45 days after emergence (DAE) (early bloom) over the plants with a hand sprayer $\left(800 \mathrm{~L} \mathrm{ha}^{-1}\right)$ at the rates of 100,200 , 300 and $400 \mathrm{mg} \mathrm{L}^{-1}$ or at 45 and $55 \mathrm{DAE}$ at $300 \mathrm{mg} \mathrm{L}^{-1}$. Two additional treatments were used: water (untreated control) and the fungicide fluazinam $\left(0.5 \mathrm{~L} \mathrm{ha}^{-1}\right)$ applied at 45 and $55 \mathrm{DAE}$. Both incidence and severity of white mold were significantly reduced with application of $\mathrm{CaCl}_{2}$ and $\mathrm{CaSiO}_{3}$, but there was no effect on yield. Fluazinam reduced significantly the disease incidence and severity by $52 \%$ and $73 \%$, respectively, and increased the yield by $31 \%$.
\end{abstract}

Keywords: Phaseolus vulgaris, Sclerotinia sclerotiorum, integrated management, alternative control.

\section{RESUMO}

Aplicação foliar de cloreto de cálcio e silicato de cálcio reduz a intensidade do mofo-branco do feijoeiro

O mofo-branco (Sclerotinia sclerotiorum) é a principal doença do feijoeiro no cultivo de outono-inverno no Brasil. O emprego de diferentes estratégias é necessário para controlar a doença e aumentar o rendimento em áreas infestadas. O objetivo deste trabalho foi verificar o efeito da aplicação de cloreto de cálcio $\left(\mathrm{CaCl}_{2}\right)$ e de silicato de cálcio $\left(\mathrm{CaSiO}_{3}\right)$ no controle do mofo-branco do feijoeiro. O experimento foi conduzido no outono-inverno de 2006, em Viçosa MG, em área naturalmente infestada com escleródios de S. sclerotiorum. Os produtos foram aplicados no início da floração, com um pulverizador manual ( $800 \mathrm{~L} \mathrm{ha}^{-1}$ ), nas doses de 100, 200, 300 e 400 mg L'-1, ou no início da floração e 10 dias após, na dose de $300 \mathrm{mg} \mathrm{L}^{-1}$. Esses tratamentos foram comparados com a aplicação de água (testemunha) e do fungicida fluazinam $\left(0,5 \mathrm{~L} \mathrm{ha}^{-1}\right)$ aplicado no início da floração e 10 dias após. A incidência e a severidade do mofo-branco foram significativamente reduzidas com a aplicação de $\mathrm{CaCl}_{2}$ e $\mathrm{CaSiO}_{3}$, sem efeito significativo no rendimento da cultura. $\mathrm{O}$ fungicida reduziu a severidade e a incidência da doença em $52 \%$ e $73 \%$, respectivamente, e aumentou o rendimento em $31 \%$.

Palavras-chave: Phaseolus vulgaris, Sclerotinia sclerotiorum, manejo integrado, controle alternativo.

More than 400 plant species including dry beans (Phaseolus vulgaris L.) are susceptible to white mold, a disease caused by Sclerotinia sclerotiorum (Lib.) de Bary (Bolland \& Hall, 1994). Approximately $35 \%$ of dry beans harvested in the State of Minas Gerais, Brazil, are produced in sprinkler irrigated areas during the fall-winter period. Most of these areas are infested with sclerotia of $S$. sclerotiorum, leading frequently to significant losses if the disease is not adequately controlled. Fungicide management is the most efficient control option available to the bean growers. The fungicide fluazinam has been used to control white mold with an initial application at early bloom and an additional application 10 days later. Other practices used to manage the disease include use of non-infested seeds, low plant population, upright cultivars, crop rotation with cereals, biological control, and low irrigation frequency (Steadman, 1979; Tu, 1997; Paula Júnior et al., 2006).
Lime, used to correct soil acidity and to supply plants with $\mathrm{Ca}$, can reduce plant susceptibility to fungal infection in some pathosystems (Vale et al., 2000). Calcium (Ca) plays an important role in the defense of plants against S. sclerotiorum, since it is essential in the structure of the middle lamellae of plant cells and in maintaining selectivity of cell plasmalemmas. Oxalic acid produced during the infection by Sclerotinia degrades the structure of plant cell walls and it is essential for disease development, although its precise role is not well understood (Maxwell \& Lumsden, 1970; Godoy et al., 1990; Zhou \& Boland, 1999). The role of oxalate in Sclerotinia pathogenicity can be explained by its affinity for $\mathrm{Ca}^{2+}$, which may weaken plant barriers by leaching the stabilizing cation from the host plant cell wall (Dutton \& Evans, 1996; Cessna et al., 2000). In some irrigated areas in Brazil farmers use Ca fertilizers with alleged good results for white mold control. 
Commonly, they apply these fertilizers through a central pivot. However, there are only preliminary reports about the benefits of $\mathrm{Ca}$ fertilizers on white mold control in the USA (Venette, 1998). It is hypothesized that since Ca plays a role in bean plant defense against white mold, application of this nutrient would reduce disease intensity. The objective with this work was to evaluate the efficacy of calcium chloride $\left(\mathrm{CaCl}_{2}\right)$ and calcium silicate $\left(\mathrm{CaSiO}_{3}\right)$ for white mold control on dry beans.

A study was carried out from May to August 2006 in an experimental area of the Federal University of Viçosa naturally infested with sclerotia of $S$. sclerotiorum, in a soil with the following characteristics at the depth of $0-20 \mathrm{~cm}$ : phosphorus $(\mathrm{P})($ Mehlich $)=44.9 \mathrm{mg} \mathrm{dm}^{-3}$, potassium $(\mathrm{K})$ $=115 \mathrm{mg} \mathrm{dm}{ }^{-3}$, aluminum $(\mathrm{Al})=0.0 \mathrm{cmol}_{\mathrm{c}} \mathrm{dm}^{-3}$, calcium $(\mathrm{Ca})=3.4 \mathrm{cmol} \mathrm{dm}^{-3}$, magnesium $(\mathrm{Mg})=0.6 \mathrm{cmol} \mathrm{dm}^{-3}$, and $\mathrm{pH}=5.7$. The cultivar Talismã (type III, carioca class) was sown in rows spaced $0.5 \mathrm{~m}$ apart. Plots had seven $3 \mathrm{~m}$-long rows. All plots received a basal fertilization of $24 \mathrm{~kg} \mathrm{ha}^{-1}$ of $\mathrm{N}, 37 \mathrm{~kg} \mathrm{ha}^{-1}$ of $\mathrm{P}$, and $40 \mathrm{~kg} \mathrm{ha}^{-1}$ of $\mathrm{K}$. Ammonium sulfate application $\left(200 \mathrm{~kg} \mathrm{ha}^{-1}\right)$ as side dressing was performed 20 days after emergence (DAE), when a solution of molybdenum ( $\left.80 \mathrm{~g} \mathrm{ha}^{-1}\right)$, as sodium molybdate, was also applied on foliage. Weeds were controlled by hand hoeing and with a commercial mixture of the herbicides fomesafen $\left(250 \mathrm{~g} \mathrm{ha}^{-1}\right)$ and fluazifop-p-butyl $\left(200 \mathrm{~g} \mathrm{ha}^{-1}\right)$. Pests were controlled, when needed, with monocrotophos $\left(400 \mathrm{~mL}^{-}\right.$ $\left.{ }^{1}\right)$. The fungicide azoxystrobin $\left(60 \mathrm{~g} \mathrm{ha}^{-1}\right)$ was applied once before flowering to protect beans against foliar diseases.

Both $\mathrm{CaCl}_{2}$ and $\mathrm{CaSiO}_{3}$ were applied at $45 \mathrm{DAE}$ (early bloom) over the plants with a hand sprayer $\left(800 \mathrm{~L} \mathrm{ha}^{-1}\right)$ at the rates of $100,200,300$ and $400 \mathrm{mg} \mathrm{L}^{-1}$ or at 45 and $55 \mathrm{DAE}$ at $300 \mathrm{mg} \mathrm{L}^{-1}$. These treatments were compared with water (untreated control) and fluazinam applications $\left(0.5 \mathrm{~L} \mathrm{ha}^{-1}\right)$ at 45 and 55 DAE. Treatments were replicated four times in a randomized complete block design. An area of $1.2 \mathrm{~m}^{2}$ (one internal row without $0.3 \mathrm{~m}$ at each end) in the plots was harvested separately at $90 \mathrm{DAE}$ for white mold evaluation. Disease incidence was calculated as the percentage of plants with symptoms. Plants were rated for disease severity index (DSI) by means of a "quarter scale" (Hall \& Phillips, 1996), where $0=$ no disease present, $1=1 \%$ to $25 \%$ of the plant with white mold symptoms, $2=26 \%$ to $50 \%$ of the plant with white mold symptoms, $3=51 \%$ to $75 \%$ of the plant with white mold symptoms, and $4=76 \%$ to $100 \%$ of the plant with white mold symptoms. DSI was calculated on a percentage basis by the following formula:

$$
\operatorname{DSI}(\%)=\frac{\sum(\text { scores of all plants })}{4 \times(\text { total number of plants })} \times 100
$$

Yield data were estimated based on mass of seeds with $12 \%$ moisture $(\mathrm{w} / \mathrm{w})$ harvested in $3.6 \mathrm{~m}^{2}$ (included the $1.2 \mathrm{~m}^{2}$ area harvested for disease evaluation). Data were subjected to variance analysis. Regression analyses were done to test the effect of rates of $\mathrm{CaCl}_{2}$ and $\mathrm{CaSiO}_{3}$ on white mold intensity and yield. Effect of two applications of fungicide and $\mathrm{CaCl}_{2}$ and $\mathrm{CaSiO}_{3}$ were compared to the untreated control by Dunnett test.

Both incidence and severity of white mold were significantly reduced by one application of $\mathrm{CaCl}_{2}$ and $\mathrm{CaSiO}_{3}$ at early bloom (Figures 1 and 2), but the level of control was not sufficient to increase yield. Two applications of either $\mathrm{CaCl}_{2}$ or $\mathrm{CaSiO}_{3}$ reduced DSI $(\mathrm{P}<0.05)$ by $36 \%$ and $30 \%$, respectively, compared to the untreated control (Table 1). Two applications of fluazinam decreased white mold incidence and severity $(\mathrm{P}<0.01)$ and increased yield $(\mathrm{P}<0.05)$ (Table 1). Fluazinam was more efficient on white mold control than $\mathrm{CaCl}_{2}$ or $\mathrm{CaSiO}_{3}$ and reduced disease incidence by $52 \%$, severity by $73 \%$, and increased yield by $45 \%$.

The applications of $\mathrm{Ca}$ contributed to reducing the intensity of white mold on dry beans, but did not affect bean yield in a soil with high amounts of this nutrient $(3.4 \mathrm{cmol}$ $\mathrm{dm}^{-3}$ ). Venette (1998) in the USA found that foliar-applied $\mathrm{Ca}$ enhanced both disease control and dry bean yield. The author suggested that $\mathrm{Ca}$ may be a nutritional supplement that increases plant resistance to white mold. Nutritional effect is particularly noticeable in the case of $\mathrm{Ca}$ compounds with high water solubility, like $\mathrm{CaCl}_{2}$. It has been suggested that plants resistant to $S$. sclerotiorum have higher Ca levels than susceptible ones (Gulya \& Miller, 2007). Resistance of beans to $S$. sclerotiorum is also associated with tolerance to oxalic acid (Tu, 1989), which captures Ca from host cell walls during infection (Dutton \& Evans, 1996).

A possible effect of foliar application of $\mathrm{Si}$

TABLE 1 - Comparison of untreated control with two applications of fluazinam, $\mathrm{CaCl}_{2}$, and $\mathrm{CaSiO}_{3}$ on white mold intensity and dry bean yield

\begin{tabular}{|c|c|c|c|}
\hline Treatment $^{1}$ & Incidence $(\%)$ & DSI (\%) & Yield $\left(\mathrm{kg} \mathrm{ha}^{-1}\right)$ \\
\hline Fluazinam & $38.4 * *$ & $11.9 * *$ & $2253 *$ \\
\hline $\mathrm{Ca} \mathrm{Cl}_{2}\left(300 \mathrm{mg} \mathrm{L}^{-1}\right)$ & $67.9 \mathrm{~ns}$ & $27.8 *$ & $1505 \mathrm{~ns}$ \\
\hline $\mathrm{CaSiO}_{3}\left(300 \mathrm{mg} \mathrm{L}^{-1}\right)$ & $72.2 \mathrm{~ns}$ & $30.4 *$ & $1793 \mathrm{~ns}$ \\
\hline Untreated control & 79.5 & 43.3 & 1553 \\
\hline C.V. $(\%)$ & 12.5 & 23.9 & 22.3 \\
\hline
\end{tabular}


Foliar application of calcium chloride and calcium silicate decreases...
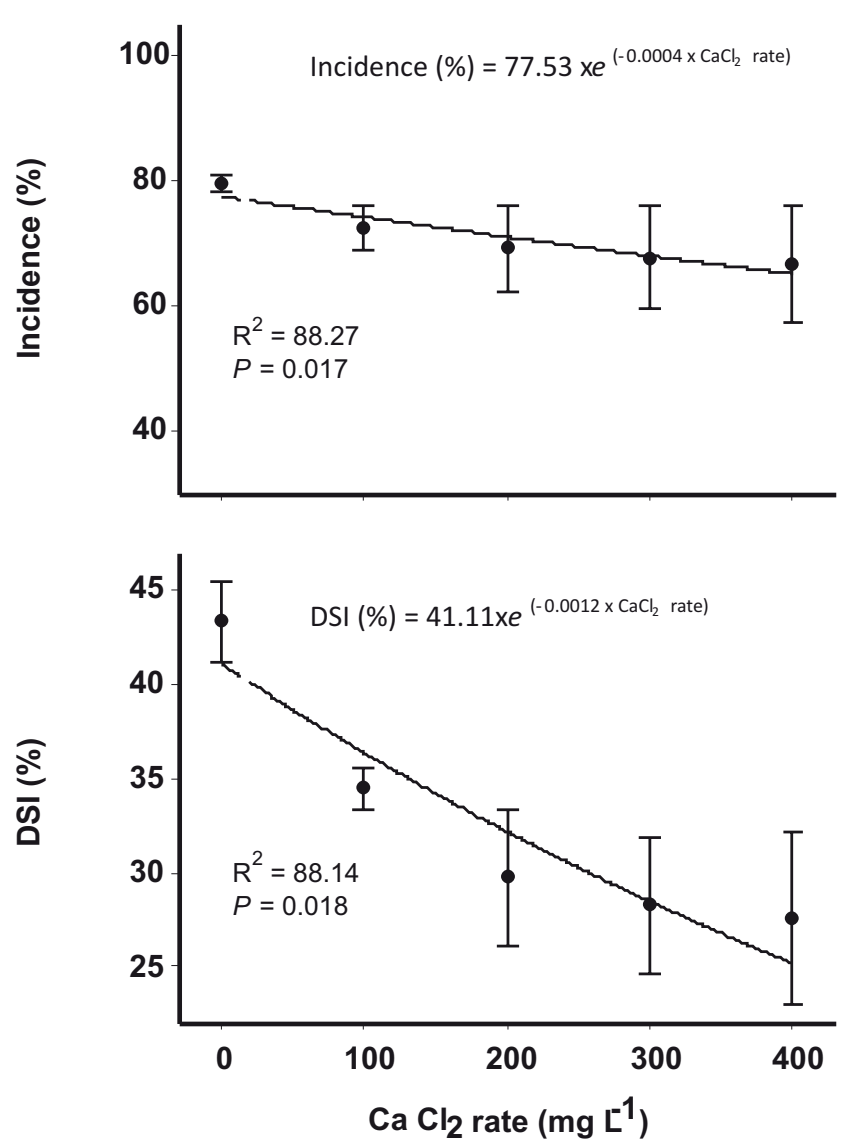

FIGURE 1 - White mold incidence and DSI in response to four rates of $\mathrm{CaCl}_{2}$ applied at early bloom (45 DAE). Each bar represents the mean \pm SD of four replications.

sources on diseases control might be explained by the establishment of a physical barrier on the host tissue (Samuels et al., 1991; Bowen et al., 1992), although on bean anthracnose (Colletotrichum lindemuthianum) $\mathrm{Si}$ applied on foliage was effective even without establishing a physical barrier (Moraes et al., 2006). Thus, increased plant resistance to diseases through $\mathrm{Si}$ treatment is associated with active and/or passive mechanisms (Datnoff et al., 2007). Effects of Si sprayed on foliage to control diseases in cucumber, muskmelon, zucchini squash (Menzies et al., 1992), common beans (Rodrigues et al., 2005a) and soybeans (Rodrigues et al., 2005b) have been described.

Many modifications may occur in the plant surface after $\mathrm{Ca}$ or $\mathrm{Si}$ application, including $\mathrm{pH}$ increase and changes in the osmotic potential and on the populations of microorganisms. Foliar application of potassium silicate, as a source of soluble silicon, decreased angular leaf spot (Pseudocercospora griseola) severity on beans at more alkaline $\mathrm{pH}$ (Rodrigues et al., 2005a). Further studies are necessary to elucidate the mechanisms that allow $\mathrm{Ca}$ to reduce white mold intensity. Such studies should include tests with calcium sulfate, one of the cheapest sources of $\mathrm{Ca}$.
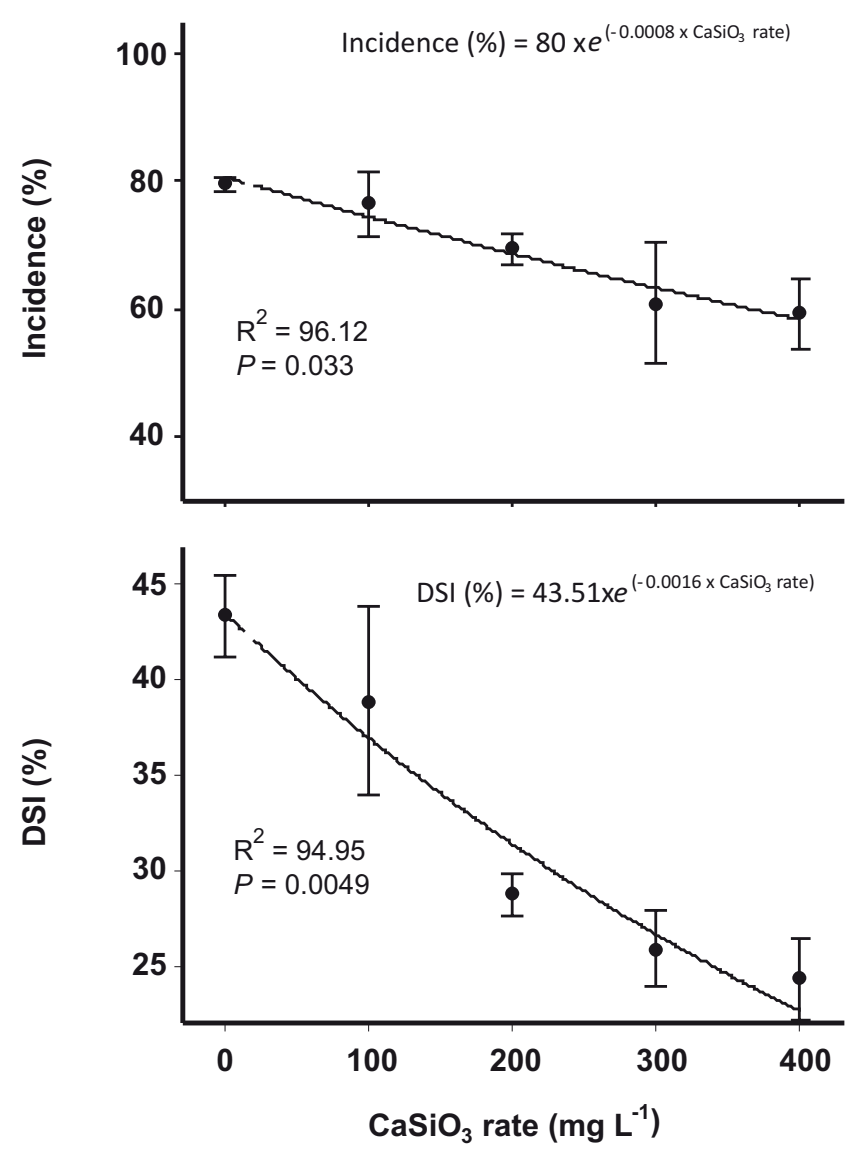

FIGURE 2 - White mold incidence and DSI in response to four rates of $\mathrm{CaSiO}_{3}$ applied at early bloom (45 DAE). Each bar represents the mean $\pm \mathrm{SD}$ of four replications.

\section{ACKNOWLEDGEMENTS}

T.J. Paula Júnior, R.F. Vieira and J.E.S. Carneiro are supported by Conselho Nacional de Desenvolvimento Científico e Tecnológico - CNPq. H. Teixeira is supported by Fundação de Amparo à Pesquisa de Minas Gerais - FAPEMIG. This project was partially supported by FAPEMIG.

\section{REFERENCES}

Bolland GJ, Hall R (1994) Index of plant hosts of Sclerotinia sclerotiorum. Canadian Journal of Plant Pathology 16:93-108.

Bowen P, Menzies J, Ehret D (1992) Soluble silicon spray inhibit powdery mildew development on grape leaves. Journal of the American Society for Horticultural Sciences 117:906-912.

Cessna SG, Sears VE, Dickman MB, Low PS (2000) Oxalic acid, a pathogenicity factor for Sclerotinia sclerotiorum, suppresses the oxidative burst of the host plant. The Plant Cell 12:2191-2199. 
Datnoff LE, Rodrigues FA, Seebold KW (2007) Silicon and Plant Disease. In: Datnoff LE, Elmer WH, Huber DM (Eds.) Mineral nutrition and plant disease. Saint Paul MN. APS Press. pp. 233246.

Dutton MV, Evans CS (1996) Oxalate production by fungi: Its role in pathogenicity and ecology in the soil environment. Canadian Journal of Microbiology 42:881-895.

Godoy G, Steadman JR, Dickman MB, Dam R (1990) Use of mutants to demonstrate the role of oxalic acid in pathogenicity of Sclerotinia sclerotiorum on Phaseolus vulgaris. Physiological and Molecular Plant Pathology 37:179-181.

Gulya TJ, Miller JF (2007) Advances in the development of sunflower germplasm with resistance to both Sclerotinia stalk rot and head rot, and the possible role of calcium in Sclerotinia resistance. Proceedings of the 2007 National Sclerotinia Initiative Annual Meeting. Minneapolis.

Hall R, Phillips LG (1996) Evaluation of parameters to assess resistance of white bean to white mold. Annual Report of the Bean Improvement Cooperative 39:306-307.

Maxwell DP, Lumsden RD (1970) Oxalic acid production by Sclerotinia sclerotiorum in infected bean and in culture. Phytopathology 60:1395-1398.

Menzies J, Bowen P, Ehret D, Glass ADM (1992) Foliar applications of potassium silicate reduce severity of powdery mildew on cucumber, muskmelon, and zucchini squash. Journal of the American Society for Horticultural Sciences 117:902-905.

Moraes SRG, Pozza EA, Alves E, Pozza AAA, Carvalho JG, Lima $\mathrm{PH}$, Botelho AO (2006) Efeito de fontes de silício na incidência e na severidade da antracnose do feijoeiro. Fitopatologia Brasileira 31:69-75.

Paula Júnior TJ, Vieira RF, Lobo Júnior M, Morandi MAB, Carneiro JES, Zambolim L (2006) Manejo integrado do mofo-branco do feijoeiro - Guia Técnico. Viçosa MG. EPAMIG-CTZM.

Rodrigues FA, Duarte HSS, Korndörfer GH, Wordell Filho JA, Zambolim L (2005a) Effect of foliar application of postassium silicate on angular leaf spot development on beans. Proceedings of the III Silicon in Agriculture Conference. Uberlândia MG.

Rodrigues FA, Duarte HSS, Korndörfer GH, Zambolim L (2005b) Effect of foliar application of postassium silicate on Asian soybean rust development on soybean. Proceedings of the III Silicon in Agriculture Conference. Uberlândia MG.

Samuels AL, Glass ADM, Ehret DL, Menzies JG (1991) Mobility and deposition of silicon in cucumber plants. Plant Cell and Environment 4:485-492.

Steadman JR (1979) Control of plant diseases caused by Sclerotinia sclerotiorum. Phytopathology 69:904-907.

Tu JC (1989) Oxalic acid induced cytological alterations differ in beans tolerant or susceptible to white mould. New Phytologist 112:519-525.

Tu JC (1997) An integrated control of white mold (Sclerotinia sclerotiorum) of beans, with emphasis on recent advances in biological control. Botanical Bulletin of Academia Sinica 38:7376 .

Vale FXR, Zambolim L, Paul PA, Costa H (2000) Doenças causadas por fungos em tomate. In: Zambolim L, Vale FXR, Costa H (Eds.) Controle de doenças de plantas: hortaliças. Viçosa MG. Suprema Gráfica e Editora. pp. 699-756.

Venette JR (1998) Calcium micronutrient may reduce white mold of dry beans. Proceedings of the Sclerotinia Workshop. Minnesota ND. In-Service Extension Workshop. Fargo.

Zhou T, Boland GJ (1999) Mycelial growth and production of oxalic acid by virulent and hypovirulent isolates of Sclerotinia sclerotiorum. Canadian Journal of Plant Pathology 21:93-99. 